\title{
PENGEMBANGAN KAWASAN WISATA BAHARI TANJUNG KELAYANG DENGAN PENDEKATAN RECREATION OPPORTUNITY SPECTRUM
}

\section{Tourism Area Development of Tanjung Kalayang Using Spectrum of Recreation Opportunity Spectrum \\ Retno Budi Wahyuni}

\author{
Manajemen Tata Hidang \\ Sekolah Tinggi Pariwisata Bandung \\ Jalan Setiabudi 186 Bandung \\ retnonaniek@gmail.com
}

Diterima: 8 April 2019. Disetujui: 25 September 2019. Dipublikasikan: 30 September 2019

\begin{abstract}
Abstrak
Aktivitas wisata bahari adalah diving, snorkling dan fishing yang tanpa disengaja mempengaruhi kualitas dan keberadaan ekosistem. Dalam pengembangan kawasan wisata bahari Tanjung Kelayang sangat dibutuhkan informasi mengenai potensi wilayah pesisir dan lautan. Secara fisik, keberadaan batu granit yang mempunyai ukuran besar serta keberagaman flora dan fauna bawah laut menjadi daya tarik Tanjung Kelayang belum dipetakan secara teknis. Hal tersebut akan berdampak pada kelanjutan kualitas dan keberadaan ekosistemnya. Recreation Opportunity Spectrum merupakan framework untuk mengidentifikasi kesempatan sebuah tempat menjadi tourism attraction. Terdapat tiga kriteria yang menjadi parameter yaitu experience, environment, locations dan examples of activities. Hasil pengukuran dari parameter tersebut menghasilkan 5 kelas mulai dari Easily Accesible sampai dengan Remote Area. Tujuan penelitian ini adalah identifikasi zona rekreasi dalam perencanaan yang tidak bertentangan dengan prinsip - prinsip pengelolaan kawasan bahari. Diharapkan dengan teridentifikasinya perwilayahan dalam bentuk kelas spektrum daerah wisata bahari disamping perencanaan aktivitas wisata dengan memperhatikan parameter dalam ROS akan menjadikan kawasan Tanjung Kelayang sebagai daerah wisata yang tidak hanya menarik wisatawan tetapi juga semakin lestari. Penelitian ini menggunakan metode deskriptif dengan pendekatan kualitatif dengan skema (1) menjabarkan potensi kawasan wisata bahari Tanjung Kelayang berdasarakan pendekatan Principal Attraction, Depth and Air, Latitude dan Acces. Kemudian setelah itu (2) dilakukan analisis dengan ROS yang menghasilkan klasifikasi kelas ROS Tanjung Kelayang. Selanjutnya (3) Hasil klasifikasi ROS tersebut akan digambar dalam bentuk GIS dengan bantuan aplikasi Arc. GIS dan Arc. Map.
\end{abstract}

(C) 2019 Asdep Industri dan Regulasi Pariwisata

Kata kunci : wisata bahari, recreational opportunity system, tanjung kelayang 


\section{ABSTRACT}

Marine tourism activities are diving, snorkeling and fishing that accidently affect the quality and existence of the ecosystem. In developing marine tourism areas, such as Tanjung Kelayang, much information needed regarding the potential of the coastal and ocean areas. Physically, the presence of granite which has a large size and diversity of flora and fauna under the sea cloud be the attractiveness of the Tanjung Kalayang that has not been technically mapped. This will affect to the quality and ecosystem sustainability. ROS is a framework for identifying opportunities for places to become tourism attractions. There are three criteria that are the parameters of ROS, namely experience, environment, location, and examples of activities. The measurement results of the ROS parameters produce 5 classes ranging from Easily Accessible to Remote Area. The purpose of this study is to identify the recreational zone which is not contrary to the principles of marine area management. It is expected that by identifying territorial in spectrum of marine tourism area classes and by managing tourism activities by paying attention to ROS parameter will make the Tanjung Kalayang area as a tourist not only attracts tourist but also more sustainable. This study uses descriptive method by with qualitative scheme: (1) to describe the potential of Tanjung Kelayang marine tourism area based on the Main Attractions, Depth and Air, Latitude and Access. (2 to analyze by using ROS parameters which resulted in ROS classification, anf the last one (3) The results of the the ROS classification will be drawn in the form of GIS by using Arc. GIS and Arc. Map application.

(C) 2019 Asdep Industri dan Regulasi Pariwisata

Keywords : marine tourism, recreational opportunity system, Tanjung Kelayang

\section{PENDAHULUAN}

Recreational Opprortunities Spectrum (ROS) dipakai oleh Pengelola Taman Nasional di Indonesia dan berbagai negara lain untuk memetakan spot yang terdapat di dalam Taman Nasional yang bisa dimanfaatkan untuk kegiatan rekreasi. Pengertian ROS menurut (Fennel, 2014, p. 92) adalah sebagai berikut;

The Recreation Opportunity Spectrum (ROS) is a system for classifying and managing recreation opportunities based on the following criteria:experience, environment, locations and examples of activities. The combination of four criteria results in five different ROS classes which are described below. A map of ROS Classes included in the map packet accompanying these document (Orams, 1999, p. 43).

Pada awalnya, model ROS dipakai oleh Dinas Kehutanan Amerika Serikat untuk menjelaskan berbagai macam kegiatan rekreasi dan pengaturan yang tersedia di hutan dan daerah alam lainnya (Gottschalk, 1986, p. 32). Model tersebut telah terbukti dan populer dalam dalam menganalisis lahan yang luas untuk rekreasi. Tingkat keberagaman peluang bagi wisatawan untuk menciptakan lingkungan bahari juga dapat dilihat sebagai spektrum (Gottschalk, 1986, p. 35).

Dalam penelitian ini akan dikaji ketersediaan zona rekreasi dalam perencanaan 
yang tidak bertentangan dengan prinsip - prinsip pengelolaan kawasan bahari. Diharapkan dengan teridentifikasinya perwilayahan dalam bentuk kelas spektrum daerah wisata bahari disamping perencanaan aktivitas wisata dengan memperhatikan parameter dalam ROS akan menjadikan kawasan Tanjung Kelayang sebagai daerah wisata yang tidak hanya menarik wisatawan tetapi juga semakin lestari. Dengan demikian permasalahan penelitian diuraikan sebagai berikut :

1. Bagaimana Experience Kawasan Wisata Bahari Tanjung Kelayang?

2. Bagaimana Environment Kawasan Wisata Bahari Tanjung Kelayang?

3. Bagaimana Locations Kawasan Wisata Bahari Tanjung Kelayang?

4. Bagaimana Examples of Activities?

Hasil penelitian lain yang dilakukan oleh Rela Trigantiarsyah Hari Mulyadi (Manajemen Pemasaran Pariwisata FPIPS UPI ) menyatakan bahwa pengembangan produk wisata dengan menggunakan spectrum ini secara bersamaan memengaruhi keputusan berkunjung ke atraksi wisata Cukang Taneuh.

\section{METODE}

Penelitian ini menggunakan metode deskriptif dengan tujuan untuk mengumpulkan informasi mengenai gejala - gejala yang ada dengan cara yang sistematis, faktual, dan akurat mengenai fakta - fakta dan sifat populasi atau daerah tertentu (Moleong, 2007, p. 24).

Pengumpulan data yang bersifat deskriptif untuk menjabarkan ROS Tanjung Kelayang dilakukan dengan pendekatan kualitatif. Dalam penelitian ini dibangun sebuag gambaran holistik dari susunan yang kompleks dan pandangan dari informan dan melakukan studi di obyek ilmiah (Moleong, 2007, p. 21). Model penelitian ini adalah (1) menjabarkan potensi kawasan wisata bahari Tanjung Kelayang berdasarkan pendekatan Principal Attraction, Depth and Air, Latitude dan Acces. Kemudian setelah itu (2) dilakukan analisis dengan ROS yang menghasilkan klasifikasi kelas ROS Tanjung Kelayang. Selanjutnya (3) Hasil klasifikasi ROS tersebut akan digambar dalam bentuk GIS dengan bantuan aplikasi Arc. GIS dan Arc. Map.

Data primer didapatkan dari hasil wawancara kepada informan (1) Aparatur Sipil Negara Dinas Pariwisata dan Ekonomi Kreatif Kabupaten Belitung yang berwenang dalam pengelolaan DTW Tanjung Kelayang, (2) Aparatur Sipil Negara Dinas Pariwisata dan Ekonomi Kreatif Kabupaten Belitung yang mempunyai masa kerja lebih dari 5 tahun dalam pengelolaan DTW Tanjung Kelayang, (3) Tour Operator yang lebih dari 5 tahun mengelola perjalanan ke pulau lengkuas serta (4) Data Checklist Wisata Bahari.

1) Data sekunder didapatkan dari BPS Kabupaten Belitung, laporan bulanan mengenai kunjungan wisatawan Bagian Pemasaran Dinas Pariwisata dan Ekonomi Kreatif Kabupaten Belitung dan hasil dari citra satelit menggunakan aplikasi Arc. GIS. Characteristics Spectrum of Marine Recreation Opportunities

a) Experience

Indikator untuk menentukan experience dilihat dari :

(1) Social Interaction with Others (15) Interaksi sosial yang terjadi di pulau tersebut.

-Coastal communities

-Cultural resources

-Ancillary activities

(2) Services and Support (10)

Ketersediaan pelayanan dan fasilitas pendukung di pulau tersebut.

-Facility

-Accommodation 
(3) Crowded (25)

Aktivitas yang biasa dilakukan secara beramai-ramai.

- Ancillary activities

- Cultural resources

- In the water activities

- On the water activities

- Coral reef resources

b) Environment

Indikator untuk menentukan environment dilihat dari :

(1) Human Influences and Structures (25)

Pengaruh kegiatan manusia dan pembangunan yang ada di setiap pulau tersebut.

-Cultural resources

-Ancillary activities

-Facility

-Accommodation

-In the water activities

-On the water activities

(2) Quality Natural Environment (15)

Kualitas lingkungan alam yang ada di setiap pulau.

- Litoral resources

-Nearshore resources

-Coral reef resources

c) Location

Indikator untuk menentukan location dilihat dari :

(1) Distance from Mainland (5)

Dekat atau tidaknya pulau tersebut dari daratan (Pantai Tanjung Kelayang).

- Accessibility

(2) Intertidal Area (5)

Area pasang surut air laut. Area ini mencakup berbagai jenis habitat, dengan berbagai jenis hewan seperti bintang laut, bulu babi, dan beberapa spesies karang.

Pengklasifikasian :
- Nilai 0-20 : Class V

- Nilai 21 - 40 : Class IV

- Nilai 41-60 : Class III

- Nilai 61-80 : Class II

- Nilai 81 - 100 : Class I

Semakin baiknya kondisi data yang masuk kedalam indikator The Spectrum of Marine Recreation Opportunities, akan membuat pembobotan nilai semakin besar, maka semakin besarnya bobot nilai pulau tersebut dapat dikategorikan kedalam Class I. Dimana nilai tertinggi adalah 100 dan nilai terendah adalah 0 .

\section{HASIL DAN PEMBAHASAN}

Wisata bahari merupakan akvitias rekreasi yang mencakup perjalanan dari tempat tinggal seseorang dan berfokus pada kegiatan di lingkungan kelautan (Orams, 1999, p. 47). Lingkungan laut yang dimaksud sebagai perairan asin dan karakteristiknya dipengaruhi oleh gelombang pasang (Garrod, 2008, p. 31)

Wisata bahari apabila dilihat dari aktivitas wisata merujuk pada marine tourism yang termasuk dalam adventure tourism (Buckley, 2010, p. 157). Pendapat yang sama dikemukakan oleh (Jennings, 2004, p. 137) bahwa mayoritas kegiatan wisata bahari termasuk dalam adventure tourism. Pengembangan dan pengelolaan wisata bahari mempunyai sifat yang sama dengan adventure tourism (Buckley, 2010, p. 159).

Karakteristik wisata bahari dalam (Buckley, 2010, p. 159) tergantung pada komponen berikut ini : 
Tabel 1 Marine Characteristic

\begin{tabular}{|c|c|c|}
\hline No & Komponen & Variasi \\
\hline A & $\begin{array}{l}\text { Principal } \\
\text { Attraction }\end{array}$ & $\begin{array}{ll}\text { - } & \text { Wildlife } \\
\text { - } & \text { Adrenalin } \\
\text { - } & \text { Scenery } \\
\text { - } & \text { Skill Sport } \\
\text { - } & \text { Thrill ride }\end{array}$ \\
\hline B & Depth and Air & $\begin{array}{ll}\text { - } & \text { SCUBA } \\
\text { - } & \text { Snorkel } \\
\text { - } & \text { Swimming } \\
\text { - } & \text { Surface }\end{array}$ \\
\hline $\mathrm{C}$ & Latitude & $\begin{array}{ll}\text { - } & \text { Polar } \\
\text { - } & \text { General } \\
\text { - } & \text { Tropical } \\
\text { - } & \text { Sub Tropical }\end{array}$ \\
\hline D & Acces & $\begin{array}{ll}\text { - } & \text { Speedboat } \\
\text { - } & \text { X cruise boat } \\
\text { - } & \text { Yacht } \\
\text { - } & \text { Tall Ship } \\
\text { - } & \text { Land } \\
\text { - } & \text { Charter Boat } \\
\text { - } & \text { Air } \\
\text { - } & \text { Sea Kayak } \\
\text { - } & \text { Jet Boat }\end{array}$ \\
\hline
\end{tabular}

Sumber : (Buckley, 2010, p. 159)

Pada tabel diatas, dalam istilah biologi merupakan "taksonomi"-nya wisata bahari. Dari karakteristik tersebut muncul jenis wisata bahari secara umum seperti berikut

1) Diving

2) Shark diving

3) Whale shark watching

4) Boat based whale watching

5) Whale watching by sea kayak

6) Boat based whale watching

7) Whale watching by sea kayak

8) Ocean coast and island by sea kayak

9) Polar expedition cruises

10) Surf charters

11) Yachting and sailing

12) Coastal powerboat tours

13) Game Fishing

14) Submarines and submersibles
Wisata bahari sangat beragam dan berkembang sejalan dengan perkembangan terestrial dan perkembangan teknologi. Perkembangan terestrial dan peralatan akan menghasilkan wisata bahari yang dapat dikomersialkan. Selain itu potensi bahari menjadi sebuah daya tarik wisata juga tergantung dari lingkungan sekitar seperti teknologi produksi perikanan dan pengelolaan limbah produksi (Williams, 2007, p. 437)

a. Pengembangan Kawasan Wisata Bahari

Pengembangan wisata bahari harus memperhatikan empat komponen yaitu active engagement, inclusivity, educative dan small scale (Williams, 2007, p. 486).

1) Active engagement

Keterlibatan aktif dari stakeholder pariwisata perlu dilakukan untuk menjamin keberlangsungan destinasi pariwisata. Di Indonesia terkenal dengan pentahelix. Menurut Peraturan Menteri Pariwisata Nomor 14 Tahun 2016 mengenai pedoman destinasi pariwisata berkelanjutan, pentahelix stakeholder pariwisata Indonesia terdiri dari akademisi, pengusaha, pemerintah, komunitas dan media.

2) Inclusivity

Pengembangan wisata bahari harus melihat karakteristik natural resources yang rentan terhadap kerusakan dan pemulihan dalam waktu yang cukup lama.

3) Educative

Sumber daya yang terdapat dalam wisata bahari mengandung nilai edukatif bagi wisatawan (Ballantyne, 2013, p. 233). Keberagaman flora dan fauna di dalam kawasan wisata bahari mempunyai keunikan tersendiri mengingat asal wisatawan dari daratan.

4) Small scale 
Small scale dalam pengembangan wisata bahari perlu menjadi pertimbangan dalam pengembangan. Semua daya tarik bahari mirip dengan daya tarik ekowisata yang bersifat rentan dengan kerusakansehingga perlu adanya pembatasan kunjungan. (Fennel D. A., 2008, p. 158)

b. The Spectrum of Marine Recreation Opportunities (ROS)

ROS merupakan framework perencanaan dan pengembangan yang diterapkan pada landscape maupun seascape dengan tujuan untuk menangani terjadinya landuse conflict melalui identifikasi experience, environment, locations dan examples of activities (Orams, Marine Tourism, 1998, p. 43). Secara ringkas dapat dilihat pada tabel berikut;

Tabel 2. Recreation Opportunity Spectrum (ROS)

\begin{tabular}{|c|c|c|c|c|c|}
\hline $\begin{array}{l}\text { Characteris } \\
\text { tics }\end{array}$ & $\begin{array}{c}\text { Class I } \\
\text { Easily accessible }\end{array}$ & $\begin{array}{c}\text { Class II } \\
\text { Accessible }\end{array}$ & $\begin{array}{c}\text { Class III } \\
\text { Less accessible }\end{array}$ & $\begin{array}{c}\text { Class IV } \\
\text { Semi-remote }\end{array}$ & $\begin{array}{l}\text { Class V } \\
\text { Remote }\end{array}$ \\
\hline Experience & $\begin{array}{l}\text { - Much social } \\
\text { interaction } \\
\text { with others } \\
\text { - High degree of } \\
\text { services and } \\
\text { support } \\
\text { - Usually } \\
\text { crowded }\end{array}$ & $\begin{array}{l}\text { Often contact } \\
\text { with other }\end{array}$ & $\begin{array}{l}\text { Some contact } \\
\text { with other }\end{array}$ & $\begin{array}{l}\text { - Peace and } \\
\text { quite, } \\
\text { close to } \\
\text { nature } \\
\text { - Safety- } \\
\text { rescue } \\
\text { available } \\
\text { - Occasiona } \\
1 \text { contact } \\
\text { with } \\
\text { others }\end{array}$ & $\begin{array}{l}\text { - Solitude } \\
\text { - Tranquility } \\
\text { - Closeness } \\
\text { to nature } \\
\text { - Self- } \\
\text { sufficiency }\end{array}$ \\
\hline Enviroment & 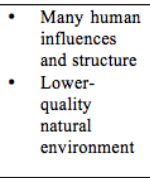 & $\begin{array}{l}\text { Human } \\
\text { structures } \\
\text { /influences } \\
\text { visible and } \\
\text { close by }\end{array}$ & $\begin{array}{l}\text { Few human } \\
\text { structure close } \\
\text { by-some visible }\end{array}$ & $\begin{array}{l}\text { Evidence of } \\
\text { some human } \\
\text { activity, } \\
\text { example } \\
\text { lights on } \\
\text { shore, } \\
\text { mooring } \\
\text { buoys }\end{array}$ & $\begin{array}{ll} & \text { Isolated } \\
& \text { High- } \\
\text { quality } \\
\text { - Few } \\
\text { human } \\
\text { structure } \\
\text { /influences }\end{array}$ \\
\hline Locations & $\begin{array}{l}\text { Close to or in } \\
\text { urban areas } \\
\text { Beaches and } \\
\text { intertidal area }\end{array}$ & $\begin{array}{l}\text { Intertidal } \rightarrow \\
100 \text { meter } \\
\text { offshore }\end{array}$ & $\begin{array}{l}100 \text { meter } \longrightarrow \\
1 \mathrm{~km} \text { offshore }\end{array}$ & $\begin{array}{l}\text { Isolated } \\
\text { coasts } \\
1-50 \quad \mathrm{kms} \\
\text { offshore }\end{array}$ & $\begin{array}{l}\begin{array}{l}\text { Uninhabited } \\
\text { coastal areas > } \\
50 \quad \text { kms } \\
\text { offshore }\end{array} \\
\end{array}$ \\
\hline $\begin{array}{l}\text { Example of } \\
\text { activities }\end{array}$ & $\begin{array}{l}\text { Sunbathing } \\
\text { People watching } \\
\text { Swimming } \\
\text { Playing games } \\
\text { Eating } \\
\text { Skimboarding } \\
\text { Sightseeing }\end{array}$ & $\begin{array}{l}\text { Swimming } \\
\text { Snorkeling } \\
\text { Fishing } \\
\text { Jet-skiing } \\
\text { Non-powered } \\
\text { boating } \\
\text { Surfing } \\
\text { Para-sailing } \\
\text { Windsurfing } \\
\end{array}$ & $\begin{array}{ll}\text { Usually boat } \\
\text { based } \\
\text { Sailing } \\
\text { Fishing } \\
\text { Snorkel scuba } \\
\text { diving }\end{array}$ & $\begin{array}{l}\text { Some scuba } \\
\text { diving } \\
\text { Submarining } \\
\text { Powerboat } \\
\text { (offshore } \\
\text { equipped) } \\
\text { Sailing-larger } \\
\text { sailboats }\end{array}$ & $\begin{array}{l}\text { Offshore } \\
\text { sailing } \\
\text { Live-aboard } \\
\text { offshore } \\
\text { fishing } \\
\text { Remote coast } \\
\text { sea-kayaking }\end{array}$ \\
\hline
\end{tabular}

Hasil observasi lapangan dengan teknik pengumpulan data telah diuraikan pada bab sebelumnya. Kawasan Bahari Pantai Tanjung Kelayang mempunyai sembilan daya tarik wisata yang terbagi menjadi dua jenis pengelolaan pengembangan yaitu Pantai / Pulau yang termasuk dalam Perencanaan Kawasan Ekonomi 62
Khusus Tanjung Kelayang yaitu (a) Pantai Tanjung Kelayang, (b) Pulau Lengkuas, (c) Pulau Pasir, (d) Pulau Babi, (e) Batu Garuda, (f) Batu Berlayar, (g) Pulau Kepayang dan Pantai / Pulau yang tidak termasuk dalam KEK Tanjung Kelayang yaitu (h) Titik Indomarine, (i) Tanjung Binga dan (j) Bukit Berahu.

\section{Identification Process}

A. Experience Kawasan Bahaari Tanjung Kelayang

a. Pantai Tanjung Kelayang

Keunikan Pantai Tanjung Kelayang terdapat pada lanscape alam yaitu pantai pasir putih, batu granit berukuran besar. Selain itu keunikan DTW Pantai Tanjung Kelayang terdapat festival, baik dari pemerintah maupun dari masyarakat lokal setiap tahunnya.

DTW Tanjung Kelayang juga mempunyai potensi untuk aktivitas penyelenggaraan event., seperti Sail Indonesia dan pernah dijadikan titik penyambutan Gerhana Matahari Total pada Tahun 2016.

Berdasarkan pada hasil observasi yang didapat peneliti, dapat diketahui bahwa DTW Pantai Tanjung Kelayang memiliki tingkat perkembangan aktivitas yang dapat dinikmati wisatawan., menandakan bahwa DTW Tanjung Kelayang dapat menambah pengalaman wisatawan mengenai wisata bahari.

Dari total penilaian berdasarkan indikator Experience (50), DTW Pantai Tanjung Kelayang memperoleh nilai 40. Dengan demikian potensi DTW Tanjung Kelayang menurut indikator experience mengarah pada pariwisata massal (mass tourism).

b. Pulau Lengkuas

Keunikan Pulau Lengkuas adalah pada menara Lengkuas setinggi 70 meter 18 lantai. Menara tersebut masih aktif digunakan oleh Kementerian Perhubungan 
Republik Indonesia dalam kegiatan pelayaran kapal laut Indonesia.

Secara umum wisatawan maupun pengelola tur perjalanan menggunakan Pulau Lengkuas sebagai point of distribution wisata bahari Kawasan Tanjung Kelayang. Atraksi yang ditawarkan DTW Pulau Lengkuas adalah lanscape alam batu granit dan pasir putih serta ombak yang tidak terlalu tinggi cocok untuk kegiatan escaping. Dari total penilaian berdasarkan indikator Experience (50), DTW Pulau Lengkuas memperoleh nilai 25 dapat mengarah pada pariwisata massal (mass tourism).

c. Pulau Pasir

DTW Pulau Pasir berbentuk sebuah pulau dimana pulau tersebut dipengaruhi oleh pasang surut air laut. Apabila air laut pasang maka pulau ini tenggelam, sebaliknya jika air laut sedang surut maka pulau ini terlihat. DTW Pulau Pasir merupakan tempat bagi hewan bintang laut.

DTW Pulau Pasir digunakan wisatawan untuk kegiatan sighteeing dan berfoto. Tidak terdapat aktivitas spesifik bahari pada DTW ini. Dengan demikian, dari total penilaian berdasarkan indikator Experience (50), DTW pulau pasir memperoleh nilai 0 .

d. Pulau Babi (Kepayang)

Keunikan DTW Pulau Kepayang terdapat pada lanscape alam yaitu pantai pasir putih, batu granit berukuran besar. Selain itu, DTW Pulau Kepayang merupakan tempat penangkaran penyu dan terumbu karang.

Tanpa adanya pungutan biaya dan pembatasan jumlah wisatawan yang datang, membuat siapa saja yang datang berkunjung dapat melihat konservasi penyu sisik dan penyu bertelur di Pulau
Kepayang, sehingga aktivitas tambahan ini dapat berpotensi dilakukan beramai-ramai oleh wisatawan. Dari keadaan tersebut dapat dikategorikan dalam kondisi yang baik dan diberikan penilaian dengan angka 5 .

Pulau Kepayang yang memiliki garis pantai pasir putih yang landai sangat baik untuk berjemur, berolahraga air seperti jet ski, berenang, scuba diving, voli pantai dan memancing. Berdasarkan pada hasil observasi yang didapat peneliti, dapat diketahui bahwa DTW Pulau Kepayang memiliki tingkat perkembangan aktivitas yang dapat dinikmati wisatawan artinya DTW Pulau Kepayang dapat menambah pengalaman wisatawan mengenai wisata bahari.

Dari total penilaian berdasarkan indikator Experience (50), DTW Pulau Kepayang memperoleh nilai 40, mengarah pada pariwisata massal (mass tourism).

\section{e. Batu Garuda}

\section{1) Experience}

Batu Garuda merupakan ikon dari Kawasan Pantai Tanjung Kelayang dengan gundukan batu menyerupai burung garuda. Dari total penilaian berdasarkan indikator Experience (50), DTW Batu Garuda memperoleh nilai 48, merupakan pariwisata massal (mass tourism).

\section{f. Pulau Batu Berlayar}

Keunikan DTW Batu Berlayar mirip dengan DTW Batu Garuda. Bentuk batu granit raksasa pada batu Berlayar menyerupai kapal yang sedang berlayar. Pada area teresebut wisatawan dapat menepi dan menikmati keunikan dari DTW Batu Berlayar dengan berfoto. Selain itu, Karakter pulau Batu berlayar merupakan habitat bagi hewan bintang laut. Dari total penilaian berdasarkan indikator Experience 
(50), DTW Batu Berlayar memperoleh nilai 15.

g. Titik Indomarine

Titik Indomarine merupakan salah satu pulau yang masuk ke dalam Gugusan Kepulauan Tanjung Kelayang dan merupakan pulau yang tidak berpenghuni dengan luas sekitar $0,67 \quad \mathrm{~km}^{2}$. Titik Indomarine dihiasi dengan indahnya terumbu karang yang menghampar luas serta keanekaragaman biota lautnya. Di pulau ini dapat ditemukan beberapa famili karang keras dan karang lunak, famili anemon, gorgonian (kipas laut) serta familia sponges (Sumber: Excotic Small Islands West Indonesia, 2008).

Dekat Titik Indomarine terdapat pulau yang memiliki pasir putih yang landai sangat cocok untuk berjemur dan melakukan aktivitas olahraga air seperti berenang, voli pantai, jet ski, dayung/kano dan snorkeling (Sumber: Perencanaan Kawasan Wisata Kabupaten Belitung,2013). Hal tersebut dapat dikategorikan Titik Indomarine dalam kondisi yang baik dan diberikan penilaian dengan angka 5.

Selain jenis terumbu karang yang beranekaragam, Titik Indomarine juga memiliki berbagai jenis ikan hias yang endemik dan tidak dijumpai pada kawasan lainnya yang hidup pada karang .Kondisi ekosistem terumbu karang di Titik Indomarine masih terjaga dan memiliki kualitas yang sangat baik karena pulau ini merupakan pulau yang tidak berpenghuni dan sedikit kunjungan wisatawan ke Titik Indomarine.

Dari total penilaian berdasarkan indikator Experience (50), Titik Indomarine memiliki total penilaian yaitu sebesar 5. Experience di Titik Indomarine sudah cukup optimal.

h. Kawasan Tanjung Binga

Keunikan kawasan Tanjung Binga adalah lanscape alam dan budaya. Keunikan alam Tanjung Binga terdapat pada pulau burung di seberang DTW Tanjung Binga. Pulau Burung mempunyai atraksi batu granit menyerupai burung dan pasir putih.

Sementara itu keunikan budaya Tanjung Binga adalah terdapat desa nelayan dengan budaya yang dimilikinya. Pada periode tertentu menggelar festival atau seremoni.

Atraksi budaya yang terbuka untuk umum, membuat wisatawan dapat turut berpartisipasi merayakannya dengan penduduk lokal.

Selain itu, terdapat potensi yang baik bagi wisatawan untuk melakukan aktivitas tambahan yaitu melihat pembuatan perahu lokal. Pulau ini tersedia fasilitas umum yang sudah baik dan memadai berupa akomodasi berupa homestay,dermaga, masjid dan pembangkit listrik tenaga surya.Dari kondisi tersebut dapat diberikan penilaian dengan angka 5 .

Tanjung Binga juga memiliki kegiatan wisata lain yaitu berupa diving dan snorkeling yang bisa dilakukan oleh wisatawan yang berkunjung ke Tanjung Binga.

Berdasarkan pada hasil observasi yang didapat peneliti, dapat diketahui bahwa DTW Tanjung Binga memiliki tingkat perkembangan aktivitas yang dapat dinikmati wisatawan, berarti dapat menambah pengalaman wisatawan mengenai wisata bahari.

Dari total penilaian berdasarkan indikator Experience (50), DTW Pantai 
Tanjung Kelayang memperoleh nilai 38 masuk kategori mass tourism.

\section{i. Bukit Berahu}

Bukit Berahu merupakan DTW yang dikelola oleh PT. Bukit Berahu Resort. Pulau ini menjadi salah satu objek wisata bahari yang ada di Kab. Belitung. Di Bukit Berahu, wisatawan dapat melakukan aktivitas berjalan - jalan mengelilingi pulau, berjemur dan menikmati sunset. Hal tersebut dapat dikategorikan dalam kondisi baik dan diberikan penilaian dengan angka 5 .

PT. Bukit Berahu Resort selaku pengelola Bukit Berahu merupakan pemangku kepentingan di DTW tersebut. PT. Bukit Berahu Resort menyediakan fasilitas berupa speedboat yang digunakan untuk mengantar wisatawan yang ingin berkunjung ke DTW bahari lainnya.

Selain itu, pengelola juga menyediakan fasilitas instalasi air bersih, jaringan telekomunikasi, sarana ibadah, gazebo, kursi pantai dan restoran serta pembangkit listrik tenaga diesel untuk kebutuhan listrik di Bukit Berahu. Akomodasi yang disediakan oleh pengelola Bukit Berahu yaitu cottage yang berjumlah 10 buah. Wisatawan yang berkunjung ke Bukit Berahu dapat menikmati fasilitas dan akomodasi yang telah disediakan oleh PT. Bukit Berahu Resort tersebut. membuat wisatawan yang berkunjung akan merasa nyaman saat berada di Bukit Berahu.

Bukit Berahu memiliki kualitas terumbu karang yang bagus dan menjadi daya tarik wisata ke Bukit Berahu. Aktivitas yang dilakukan untuk melihat daya tarik bawah laut tersebut adalah snorkeling dan diving. Nuansa keindahan bawah laut yang indah di Bukit Berahu terdapat pada zona pemanfaatan yang ada di bagian barat dimana dikhususkan untuk lokasi aktivitas snorkeling dan diving. Namun dari hasil penelitian dan kondisi aktual tidak terlihat adanya pemanfaatan area di sekitar Bukit Berahu untuk kegiatan jet ski.

Dari total penilaian berdasarkan indikator Experience (50), DTW Bukit Berahu memperoleh nilai 38. Indikator experience mengarah pada pariwisata massal (mass tourism).

B. Environmen Kawasan Tanjung Kelayang

a. Pantai Tanjung Kelayang

Kegiatan pembangunan fisik dan aktivitas di DTW Pantai Tanjung Kelayang sangat aktif. Hal tersebut didasari oleh penetapan Tanjung Kelayang sebagai Kawasan Ekonomi Khusus (KEK) Pariwisata. Sehingga pembangunan fisik dan aktivitas di DTW Pantai Tanjung Kelayang diarahkan pada pemenuhan kebutuhan KEK Pariwisata. Pembangunan fisik mengarah pada sustainable tourism, maka tidak akan merusak lingkungan alam dan budaya.

Dari total penilaian berdasarkan indikator environment (40), maka DTW Pantai Tanjung Kelayang memiliki total penilaian sebesar 40, berarti sangat optimal.

C). Location

Akses menuju DTW Pantai Tanjung Kelayang mudah dijangkau dengan kendaraan pribadi. Jalan akses menuju DTW Pantai Tanjung Kelayang dalam kondisi sangat baik, tidak ada kemacetan dan jalan relatif mulus tidak berlubang. Dari total penilaian berdasarkan indikator Location (10), DTW Pantai Tanjung Kelayang memiliki total penilaian yaitu sebesar 10., sangat optimal sudah optimal.

b . Pulau Lengkuas

Terdapat aktivitas pelayaran di sekitar pulau Lengkuas pada setiap hari dan lampu mercusuar Lengkuas dioperasikan pada jam 17.00 - 06.00 
WIB. Sistem pembuangan limbah menggunakan sistem tandon limbah dan kolam sampah kering yang nantinya dibakar. Hal tersebut cukup efektif dalam pengelolaan limbah di DTW Pulau Lengkuas. Sementara itu, sumber air berasal dari tandon tadah hujan dan pengadaan air galon kemasan dari pulau Belitung. Dari total penilaian berdasarkan indikator Environment (40), maka DTW Pulau Lengkuas memiliki total penilaian sebesar 10. Dengan demikian dapat diketahui bahwa perkembangan environment di DTW Pantai Tanjung Kelayang sudah cukup optimal.

\section{3) Location}

Akses dari daratan terdekat yaitu DTW Pantai Tanjung Kelayang sebagai starting point wisata bahari ditempuh dengan jarak $5,5 \mathrm{~km}$ atau 1 jam dengan kapal berjenis bukan speed boat. Dari total penilaian berdasarkan indikator Location (10), DTW Pantai Pulau Lengkuas memiliki total penilaian yaitu sebesar 10. Dengan demikian dapat diketahui bahwa perkembangan Location di DTW Pulau Lengkuas sudah optimal.

c. Pulau Pasir

Pada DTW Pulau Pasir tidak terdapat interaksi dari masyarakat dalam pembangunan sehingga kondisi DTW Pulau pasir sangat tergantung dari kondisi alam. Dari total penilaian berdasarkan indikator Environment (40), maka environment di DTW Pulau Pasir sudah cukup optimal.

d. Pulau Babi (Kepayang)

Pulau Kepayang merupakan kawasan penangkaran penyu dan terumbu karang yang dikonservasi oleh Pemerintah Daerah Kabupaten Belitung. Pembangunan fisik dan aktivitas pada DTW Pulau Kepayang tidak akan mempengaruhi ekosistem penyu dan terumbu karang.

Tidak adanya pembatasan pembangunan fasilitas dan pembatasan jumlah pengunjung dan akomodasi yang dibangun di Pulau Kepayang berpotensi dapat merusak lingkungan dan ekosistem penyu yang bertelur di sana.

Di Pulau Kepayang terdapat hamparan terumbu karang yang indah dengan jenis species seperti Tubastru, Mentipora, Pavona, Melliopa serta hamparan terumbu karang yang sangat indah terlihat bila dilakukan penyelaman. Berdasarkan penjelasan di atas, kondisi kualitas lingkungan terumbu karang yang ada di Pulau Kepayang masih baik.Sehingga dari total penilaian berdasarkan indikator Environment (40), maka DTW Pulau Kepayang memiliki total penilaian sebesar 40. ,sudah cukup optimal.

e. Batu Garuda

Dalam pengembangan kawasan DTW Batu Garuda, tidak terdapat interaksi masyarakat dan semuanya masih bersifat alami.

Dari total penilaian berdasarkan indikator Environment (40), maka DTW Pantai Tanjung Kelayang memiliki total penilaian sebesar 10, DTW Pantai Tanjung Kelayang sudah cukup optimal.

f. Pulau Batu Berlayar

Dalam pengembangan kawasan DTW Batu Berlayar, tidak terdapat interaksi masyarakat dan semuanya masih bersifat alami.

Dalam klasifikasi yang bedasarkan karakteristik bahari, DTW Batu Berlayar dapat digolongkan dalam kategori pulau yang dapat diakses atau dicapai dengan mudah. Hal ini dilihat posisi pulau yang sangat dekat dengan daratan Tanjung Kelayang dan masih dapat terlihat dari 
daratan utama yaitu dari Pelabuhan Tanjung Kelayang.

Dari total penilaian berdasarkan indikator Environment (40), maka DTW Batu Berlayar memiliki total penilaian sebesar 15, perkembangan environment di DTW Batu Berlayar sudah cukup optimal.

g. Titik Indomarine

Flora yang terdapat di DTW Titik Indomarine seperti, padang lamun, pinus dan pohon kelapa. Fauna yang ada seperti, udang kipas, teripang, lobster, bulu babi dan ikan kakap merah atau ikan sunu. Karena tidak berpenghuni dan jarang dikunjungi wisatawan, fauna berupa bulu babi dan florayang tersedia masih memiliki kualitas yang baik di Titik Indomarine. Dari kondisi tersebut dapat dilihat bahwa kondisi lingkungan di Titik Indomarine dalam kondisi yang baik dan diberikan penilaian dengan angka 5.

Dari total penilaian berdasarkan indikator Environment (40), maka DTW Titik Indomarine memiliki total penilaian sebesar 15. Dengan demikian dapat diketahui bahwa perkembangan environment di DTW Titik Indomarine sudah cukup optimal.

h. Kawasan Tanjung Binga

Selain itu, minimnya fasilitas tempat pembuangan sampah dapat memberi dampak berupa penurunan kualitas lingkungan di Tanjung Binga. Dengan adanya pembangunan akomodasi maupun fasilitas, tanpa adanya regulasi mengenai pembangunan yang boleh dilakukan maupun yang tidak diperbolehkan, hal tersebut dapat memberi dampak berupa rusaknya kondisi kestabilan tanah di Tanjung Binga.

Belum adanya pembatasan terhadap jumlah wisatawan yang dapat melakukan aktivitas snorkeling maupun diving dapat berpotensi menimbulkan kerusakan terumbu karang serta biota laut yg ada.
Tanjung Binga memiliki sumber daya terumbu karang yang bagus. Selain memiliki sumber daya terumbu karang yang bagus, Pulau ini memiliki fauna laut seperti kepiting. Menurut masyarakat sekitar, "Mata pencaharian utama masyarakat Tanjung Binga adalah nelayan". Meskipun sudah berpenghuni, kondisi terumbu karang di Tanjung Binga masih terjaga dengan baik.

Dari total penilaian berdasarkan indikator Environment (40), maka DTW Tanjung Binga memiliki total penilaian sebesar 35 , environment di DTW Tanjung Binga sudah cukup optimal.

\section{3) Location}

Dari total penilaian berdasarkan indikator Location (10), DTW Tanjung Binga memiliki total penilaian yaitu sebesar 10 , perkembangan Location di DTW Tanjung Binga sudah optimal.

\section{i. Bukit Berahu}

\section{2) Environment}

Adanya zona pemanfaatan yang digunakan untuk aktivitas diving dan snorkeling tidak berpengaruh terhadap ekosistem terumbu karang yang dikonservasi karena berbeda zona. Pengelola telah melakukan zonasi terhadap perairan di sekitar Bukit Berahu sehingga ekosistem terumbu karang yang sensitif tidak terpengaruh oleh adanya kegiatan wisata di Bukit Berahu.

Dari data tersebut dapat diketahui bahwa kualitas lingkungan alam di Bukit Berahu termasuk dalam kondisi yang baik karena masih terdapat banyaknya terumbu karang hidup dan di sekitar pulau tersebut.

Selama ini Bukit Berahu memiliki kualitas lingkungan yang sangat baik. Namun, setelah dikelola oleh pihak swasta, kualitas lingkungan tersebut dimanfaatkan dengan dibuatnya zonasi 
bagi aktivitas wisata seperti diving dan snorkeling serta zonasi bagi kegiatan konservasi ekosistem terumbu karang.

Dari total penilaian berdasarkan indikator Environment (40), maka DTW Bukit Berahu memiliki total penilaian sebesar 35, environment di DTW Bukit Berahu sudah optimal.

C. Location Kawasan Tanjung Kelayang

a. Pantai Tanjung Kelayang

Akses menuju DTW Pantai Tanjung Kelayang mudah dijangkau dengan kendaraan pribadi. Jalan akses menuju DTW Pantai Tanjung Kelayang dalam kondisi sangat baik, tidak ada kemacetan dan jalan relatif mulus tidak berlubang. Dari total penilaian berdasarkan indikator Location (10), DTW Pantai Tanjung Kelayang memiliki total penilaian yaitu sebesar 10., sangat optimal sudah optimal.

b. Pulau Lengkuas

Akses dari daratan terdekat yaitu DTW Pantai Tanjung Kelayang sebagai starting point wisata bahari ditempuh dengan jarak 5,5 km atau 1 jam dengan kapal berjenis bukan speed boat. Dari total penilaian berdasarkan indikator Location (10), DTW Pantai Pulau Lengkuas memiliki total penilaian yaitu sebesar 10. Dengan demikian dapat diketahui bahwa perkembangan Location di DTW Pulau Lengkuas sudah optimal.

\section{c. Pulau Pasir}

Lokasi Pulau Pasir tidak jauh dari DTW Pantai Tanjung Kelayang. Jarak dari DTW Pantai Tanjung Kelayang adalah 1,5 km dengan kapal. Dari total penilaian berdasarkan indikator Location (10), DTW Pantai Tanjung Kelayang memiliki total penilaian yaitu sebesar 10. Dengan demikian dapat diketahui bahwa perkembangan Location di DTW Pulau Pasir sudah optimal. d. Pulau Babi (Kepayang)

Jarak DTW Pulau Babi dari mainland adalah 2,5 km. Hanya dapat dijangkau dengan transportasi laut dalam waktu 30 menit.

Dari total penilaian berdasarkan indikator Location (10), DTW Pulau Babi memiliki total penilaian yaitu sebesar 5, sudah optimal.

\section{e. Batu Garuda}

Letak DTW Batu Garuda tidak jauh dari starting point wisata bahari Tanjung Kelayang yaitu sejauh $0,7 \mathrm{~km}$ dan ditempuh dalam waktu 15 menit perjalanan dengan menggunakan kapal. Dengan demikian dapat diketahui bahwa DTW Batu Garuda sangat dekat dengan daratan utama yaitu Pantai Tanjung Kelayang.

Dari total penilaian berdasarkan indikator Location (10), DTW Batu Garuda memiliki total penilaian yaitu sebesar 10 , jadi sudah optimal.

f. Pulau Batu Berlayar

Dari total penilaian berdasarkan indikator Location (10), DTW Batu Berlayar memiliki total penilaian yaitu sebesar 10, location di DTW Batu Berlayar sudah optimal.

\section{g. Titik Indomarine}

Untuk akses menuju pulau ini jika ditempuh dari DTW Pantai Tanjung Kelayang dengan menggunakan boat akan memakan waktu 1 jam. Sedangkan jika dari DTW Tanjung Binga dengan menggunakan perahu motor, waktu yang ditempuh lebih lama yaitu sekitar 1,5 jam. Dari kondisi tersebut dapat dikategorikan bahwa lokasi DTW Titik Indomarine dalam keadaan cukup dan diberikan penilaian 5 .

Sebagai pulau yang masuk dalam gugusan kepulauan Tanjung Kelayang, DTW Titik Indomarine memiliki letak yang cukup dekat dengan pulau yang menjadi daya tarik utama yaitu Pulau Lengkuas. DTW Titik Indomarine memiliki potensi sebagai pulau yang 
berfungsi untuk tempat transitnya wisatawan sebelum menuju Pulau Kapoposang.

h. Kawasan Tanjung Binga

Dari total penilaian berdasarkan indikator Location (10), DTW Tanjung Binga memiliki total penilaian yaitu sebesar 10 , perkembangan Location di DTW Tanjung Binga sudah optimal.

i. Bukit Berahu

Dari total penilaian berdasarkan indikator Location (10), DTW Bukit Berahu memiliki total penilaian yaitu sebesar 10,perkemb angan Location di DTW Bukit Berahu sudah optimal

\section{Classification Process}

Berikut adalah hasil classifaction process pada masing masing zona area di pulau2 di Tanjung Kelayang

Tabel 3. Tabel Hasil Penilaian Kawasan Tanjung Kelayang Berdasarkan The Spectrum of Marine Recreation Opportunities

\begin{tabular}{|c|c|c|c|c|c|c|c|c|c|}
\hline \multirow[b]{2}{*}{ Nama DTW } & \multicolumn{3}{|c|}{ Experience } & \multicolumn{2}{|c|}{ Environment } & \multicolumn{2}{|c|}{ Location } & \multirow[b]{2}{*}{ Total } & \multirow{3}{*}{ Kelas } \\
\hline & $\begin{array}{c}\text { Social } \\
\text { Interaction } \\
\text { With Other }\end{array}$ & $\begin{array}{c}\text { Services } \\
\text { and Support }\end{array}$ & Crowded & \begin{tabular}{|c|} 
Human \\
Influences \\
and \\
Structures \\
\end{tabular} & $\begin{array}{c}\text { Quality } \\
\text { Natural } \\
\text { Environment } \\
\end{array}$ & $\begin{array}{c}\text { Distance } \\
\text { From } \\
\text { Mainland } \\
\end{array}$ & $\left|\begin{array}{c}\text { Interencitical } \\
\text { Area }\end{array}\right|$ & & \\
\hline & 15 & 10 & 25 & 25 & 15 & 5 & 5 & 100 & \\
\hline Pantai Tanjung Kelayang & 10 & 10 & 20 & 25 & 10 & 5 & 5 & 85 & 1 \\
\hline \begin{tabular}{|l|} 
Pulau Lergkuas \\
\end{tabular} & 10 & 5 & 10 & 5 & 5 & 5 & 5 & 45 & IIII \\
\hline Pulau Pasir & & & & & 15 & 5 & 5 & 25 & IV \\
\hline Pulau Babi (Kepayang) & 15 & 5 & 20 & 15 & 15 & 5 & 5 & 80 & II \\
\hline Batu Garnda & 15 & 8 & 25 & & 15 & 5 & 5 & 73 & II \\
\hline Titik Indomarine & & & & 5 & 10 & 5 & 5 & 25 & IV \\
\hline Batu Berlayat & 5 & 5 & 5 & & 5 & 5 & 5 & 30 & IV \\
\hline \begin{tabular}{|l|} 
Kawasn Tanjung Binga \\
\end{tabular} & 10 & 10 & 18 & 25 & 10 & 5 & 5 & 83 & 1 \\
\hline Bukit Berahu & 15 & 10 & 13 & 25 & 10 & 5 & 5 & 83 & 1 \\
\hline
\end{tabular}

Sumber : Data Olah Penelitian, 2018

Keterangan :

- Total skor 81 - 100: Kelas I

- Total skor 61-80 : Kelas II

- Total skor 41-60 : Kelas III

- Total skor 21-40 : Kelas IV

- Total skor 0-20 : Kelas V

\section{SIMPULAN}

DTW Tanjung Kelayang, Tanjung Binga dan Bukit Berahu termasuk dalam Kelas I atau accesible, yang berarti di pulau tersebut terdapat adanya interaksi dengan masyarakat lokal atau pengunjung lainnya, banyak bangunan dan fasilitas yang mempengaruhi jarak pandang tetapi wisatawan leluasa apabila ingin melihat, mengapresiasi dan menikmati pemandangan alamnya.

Pulau Lengkuas, Pulau Kepayang dan Batu Garuda masuk kedalam kelas II dan III atau cukup terjangkau, yang berarti di pulau tersebut jauh dari pusat keramaian sehingga kondisinya lebih damai, sepi dan lebih dekat dengan alam, serta masih adanya aktifitas kehidupan manusia.

Pulau Pasir, Titik Indomarine, Batu Berlayar masuk kedalam kelas IV atau terpencil yang berarti di pulau ini pengunjung dapat menikmati suasana yang sangat tenang dan jauh dari keramaian, dapat menikmati kesendirian dan kemandirian yang memungkinkan pengunjung untuk lebih dekat dengan alam. Hanya sedikit pengaruh manusia di pulau ini, sehingga kualitas DTW masih terjaga dengan baik. Beberapa hal yang harus diperhatikan dalam merencanakan pengembangan wisata minat khusus ekowisata bahari adalah :

\section{a. Product Attractions}

Dalam upaya menciptakan produk wisata minat khusus ekowisata bahari umumnya bermula dari hal yang tidak biasa dan terkesan unik. Oleh karena itu, pasar yang dituju sangat terbatas dan segmented. Misalnya dalam kegiatan konservasi kita dapat melihat atau bahkan terlibat langsung dalam kegiatan tersebut, sebagai contoh : transplantasi terumbu karang, melihat penyu hijau bertelur, mempelajari kegiatan budidaya kuda laut, melakukan aktivitas melihat fauna langka di bawah laut. Hal-hal tersebut termasuk dalam pengembangan wisata minat khusus.

b. Access

Akses di kawasan ekowisata bahari tersebut tidak perlu dibuat sedemikian rupa, 
cukup dibuat sebagaimana adanya seperti jalan berbatu atau kayu yang untuk menjaga kealamian kawasan tersebut. Faktor aksesibilitas yang dimaksud lebih cenderung kepada kemudahan pencapaian ekowisatawan ke daerah pulau tersebut.

\section{c. Attitudes}

Attitudes, dalam hal ini Special Interest Tourism tersebut harus bernilai atau mempunyai karakter yang khas/berbeda dari yang lain dan dikemas secara baik.

Kualitas dari produk yang unik, bernilai dan berkualitas adalah :

1) Bermanfaat terhadap ekowisatawan

2) Memberikan keterampilan khusus kepada ekowisatawan

3) Mempunyai filosofis dan etos sosial

4) Produk bersifat berkelanjutan, yaitu produk akan bertahan lama dan tidak akan dapat cepat berubah karena tren pariwisata yang berkembang (Read: 1980)

Contoh kegiatan yang bermanfaat terhadap wisatawan ini seperti, adanya kegiatan transplantasi terumbu karang. Memberikan keterampilan khusus kepada ekowisatawan. Hal ini berhubungan dengan pengetahuan dan keterampilan khusus yang berkaitan dengan aktivitas yang memerlukan pelatihan yang akan didapat oleh wisatawan. Contoh aktivitas ini seperti adanya pelatihan untuk melakukan diving atau snorkeling yang diberikan oleh instruktur selam kepada wisatawan.Diadakannya aktivitas donasi akan menimbulkan rasa memiliki dari wisatawan untuk menjaga terumbu karang Tanjung Kelayang.Produk bersifat berkelanjutan. ,contoh produk berkelanjutan seperti, adanya produk ekowisata seperti transplantasi terumbu karang. Bertujuan untuk pelestarian terumbu karang serta dengan memanfaatkan penduduk lokal setempat untuk turut berpartisipasi membuat produk wisata ini memiliki sifat berkelanjutan. Selain itu juga Selain ititu juga 70 terdapat produk wisata berupa kkonservasi penyu sisik

\section{DAFTAR PUSTAKA}

\section{Buku}

Ballantyne, R. (2013). International Handbook for Ecotourism. Queensland: Edwar Elgar Publishing.

Buckley, R. (2010). Adventure Tourism Management. Oxford: butterworth heinemann.

Fennel, D. A. (2008). Codes of Ethics in Tourism. Toronto: Channel View Publications.

Fennel, D. E. (2014). Ecotourism Fourth Edition. London, Canada: Routlege.

Garrod, B. (2008). New Frontiers in Marine Tourism : Diving Experiences, Sustainablity Management. Oxford: Elsevier.

Gottschalk, L. (1986). Understanding History; A Primer of Historical Method (terjemahan Nugroho Notosusanto). Jakarta: UI Press.

Hassan, i. (2008). Analisis Data Penelitian dengan Statistik. Jakarta: Bumi Aksara.

Jennings, g. (2004). Mediating Meaning : Perspective on Brokering Quality Tourist Experience. Melbourne: Monash University Working Paper Series.

Moleong, L. J. (2007). Metodologi Penelitian Kualitatif. Bandung: PT Remaja Rosdakarya Offset.

Orams, m. (1998). Marine tourism. London: routlege.

Orams, M. (1999). Marine Tourism : Development, Impact ad Management. London: Routlege.

Williams, a. M. (2007). A Companion to Tourism. Exeter: Blackweel Publishing. 


\section{Artikel}

Trigantiarsyah,Rela dan Mulyadi, Hari. Pengembangan Produk Wisata dengan Menggunakan Teknik Tourism Opportunity Spectrum terhadap Keputusan Berkunjung (Survei Pada Pengunjung Cukang Taneuh/Green Canyon Kabupaten Ciamis). Diakses dari Tourism and Hospitality Essentials (THE) Journal, Vol.II, No.1, 2012 177.http://ejournal.upi.edu

\section{Peraturan perundang-undangan}

Dinas Pariwisata dan Ekonomi Kreatif Kabupaten Belitung. Rencana Strategis Pariwisata Kabupaten Belitung 2013 2018. Kabupaten Belitung: Dinas Pariwisata dan Ekonomi Kreatif. 